ĐOKO TRIPKOVIĆ, naučni savetnik

Institut za savremenu istoriju

UDK 327(497.1:47)"1969/1973"

Beograd, Trg Nikole Pašića 11

327(497.1)"1969/1973"

\title{
OBNOVA POLITIČKOG DIJALOGA NA NAJVIŠEM NIVOU IZMEĐU BEOGRADA I MOSKVE POČETKOM 70-ih GODINA 20. VEKA*
}

\begin{abstract}
APSTRAKT: U članku se razmatra pitanje obnove političkog dijaloga između Beograda i Moskve na najvišem nivou početkom 70-ih godina 20. veka. Obnova dijaloga predstavljala je kompleksno pitanje s obzirom na izuzetno loše stanje u odnosima Jugoslavije i SSSR-a koje je nastalo povodom vojne intervencije u Čehoslovačkoj. Uspostavljanjem $i$ učvršćenjem političke komunikacije na vrhu (1971-1973) otvorena je perspektiva za napredak bilateralne saradnje na svim poljima, a taj trend se nastavio, uz manje oscilacije, tokom cele te decenije.
\end{abstract}

Ključne reči: Jugoslavija, SSSR, Tito, Berežnjev, dijalog, Hladni rat

Vojna intervencija SSSR-a i još četiri članice Varšavskog pakta u Čehoslovačkoj, avgusta 1968, imala je za posledicu drastično pogoršanje, praktično zamrzavanje političkih odnosa između Jugoslavije i SSSR-a. Međutim, žestoke optužbe koje su dve strane razmenjivale neposredno posle intervencije postepeno su splašnjavale, da bi se tokom 1969. tenzije u međusobnim odnosima gotovo potpuno stišale. Da u Beogradu i Moskvi nisu želeli da čehoslovački slučaj ima za posledicu dugoročnije pogoršanje odnosa moglo se videti iz razmene pisama između Josipa Broza Tita i Leonida Brežnjeva, oktobra 1968, kada su lideri dve zemlje, i pored toga što su zadržali stavove i ocene u vezi sa Čehoslovačkom, ipak ostavili otvorena vrata za normalizaciju odnosa. ${ }^{1}$ Rukovodstva dve zemlje nisu želela da se ponovi situacija slična onoj nastaloj sukobom iz 1948, posle kojeg su godinama međusobni odnosi bili izrazito loši. I jedna i druga strana su procenile da nije u njihovom interesu da dramatično pogoršanje povodom događaja u Čehoslovačkoj predugo traje, tako da su tokom proleća i leta 1969. preduzeti koraci u pravcu normalizacije političkih odnosa, što je i zvanično manifestovano posetom Andreja Gromika, člana najviše partijskog rukovodstva i ministra

\footnotetext{
${ }^{*}$ Rad je deo projekta Srpsko društvo u jugoslovenskoj državi u 20. veku-Između demokratije i diktature (177016) koji finansira Ministarstvo prosvete i nauke Republike Srbije.

${ }^{1}$ Đ. Tripković, Prepiska Tita sa Leonidom Brežnjevom i Lindonom Džonsonom povodom događaja u Čehoslovačkoj 1968, Istorija 20. veka, 2, 2010, 175-187.
} 
inostranih poslova SSSR-a, Jugoslaviji početkom septembra te godine. U razgovorima koji su tom prilikom vođeni iskazana je spremnost rukovodstava dve zemlje da, uprkos razlikama koje postoje, poboljšaju političke odnose i nastave bilateralnu saradnju, čime je praktično uklonjen slučaj Čehoslovačke kao faktor u daljem razvoju jugoslovensko-sovjetskih odnosa. ${ }^{2}$

I jedna i druga strana su imale evidentne interese i motive za ovakav politički kurs. Za sovjetsko vođstvo, koje je posle vojne intervencije u Čehoslovačkoj nastojalo da sanira političku štetu koju je zbog tog akta SSSR pretrpeo na međunarodnom planu, normalizacija i poboljšanje političkih odnosa sa Jugoslavijom bili su značajna stavka u sklopu tih napora. Inače, u to vreme je kao važan segment ukupnog spoljnopolitičkog koncepta SSSR-a osmišljena, a potom lansirana ideja o sazivanje konferencije o evropskoj bezbednosti (KEB), čiji je suštinski cilj bio da se na jednoj takvoj konferenciji donesu akti kojima bi se osigurao dugoročan opstanak postojeće političke konstelacije u Evropi, to jest očuvanje sovjetske dominacije u Istočnoj Evropi kao tekovine proizašle iz rezultata Drugog svetskog rata. U Moskvi se s razlogom procenjivalo da bi Jugoslavija - imajući u vidu njen međunarodni položaj, značajnu ulogu u međunarodnim odnosima, posebno u pokretu nesvrstanih, kao i njen spoljnopolitički nastup u kojem su snažno zastupani principi očuvanja mira i bezbednosti u svetu - imala interes ne samo da podrži ovu inicijativu već, verovatno, i da se aktivnije angažuje oko priprema i samog održavanja KEB-a. Treba svakako imati u vidu još jedan razlog koji je navodio sovjetsku stranu na poboljšanje političkih veza sa Jugoslavijom. U sovjetskoj globalnoj politici u to vreme bila je sve vidljivija orijentacija ka jačanju sovjetskog prisustva i uticaja na Mediteranu, Bliskom istoku i u Africi, tako da se na Jugoslaviju zbog njenog geopolitičkog položaja - izlaz na Jadransko more i vrlo dobri odnosi sa većinom zemalja ovih regiona - računalo u sovjetskim planovima za pojačano angažovanje u ovom delu sveta. Narednih godina to se pokazalo i u praksi, naročito kroz sovjetske zahteve za korišćenje jadranskih luka za remont brodova i prelete aviona preko jugoslovenskog vazdušnog prostora.

$\mathrm{Na}$ ovakav kurs sovjetske politike uticala je i činjenica vezana za sudbinu Jugoslavije posle Tita, o čemu su vršene ozbiljne analize i procene u relevantnim službama velikih sila, dok su u zapadnoj štampi bili sve češći napisi u kojima se spekulisalo na tu temu. Tito je već bio na samom pragu devete decenije života, a i ostali iz ,ratne generacije“", koji su već četvrt veka upravljali zemljom, bili su na izmaku radnog veka. Pitanje ,šta će biti posle Tita“ postalo je relevantno pitanje za sve faktore koji su imali interes u pogledu Jugoslavije. Jedan od njih, i to vrlo značajan, bio je i SSSR. I analitičari u Moskvi su se bavili ovim pitanjem i došli su do logičkog zaključka da bi izgradnjom boljih političkih veza sa Beogradom bile znatno ojačane sovjetske pozicije u Jugoslaviji a time i uticaj na pravac kojim će ta zemlja ići posle Tita.

${ }^{2}$ Đ. Tripković, Vraćanje balansa u politici Jugoslavije prema supersilama krajem 60-ih godina 20. veka, Tokovi istorije, 2, 2010, 75-94. 
Interes Tita i jugoslovenskog rukovodstva za normalizacijom i poboljšanjem političkih odnosa sa SSSR-om prvenstveno je proisticao iz potrebe održavanja balansa između Istoka i Zapada, politike na kojoj se još od sredine 50-ih godina temeljila stabilnost međunarodnog položaja Jugoslavije. Ta potreba je bila utoliko veća što je jugoslovensko rukovodstvo - suočeno sa sve izraženijim unutrašnjim političkim tenzijama koje su prvenstveno generisane sve otvorenijim ispoljavanjem separatističkih težnji (Slovenija, Kosovo, Hrvatska) kao i sa nagomilanim ekonomskim i socijalnim problemima koji su posle neuspele privredne reforme postali još teži - na prelazu iz 60-ih u 70-te sve otvorenije i odlučnije zauzimalo kurs jačanja političkog monopola SKJ i suzbijanja liberalističkih pojava i težnji u političkom životu, privredi i u oblasti kulture i umetničkog stvaralaštva. To je, inače, bio deo scenarija sveobuhvatne transformacije jugoslovenskog društva i države čiji je glavni idejni tvorac, ali i praktični realizator, bio Edvard Kardelj. Proces transformacije okončan je 1974, pravnom kodifikacijom kroz novi ustav i ideološkim postulatima usvojenim na 10. kongresu SKJ te iste godine. Naglašavanje vladajuće uloge SKJ - čime se značajno ublažavala verovatno najznačajnija ideološka razlika između sovjetske i jugoslovenske partije oko koje je teklo sporenje još od formulisanja SKJ kao „vodeće“, a ne kao „rukovodeće“ snage u društvu na partijskom kongresu 1958 - nailazilo je na povoljan prijem u Moskvi. Time je otvaran prostor za bolju i intenzivniju političku komunikaciju između Beograda i Moskve, što se potom pozitivno odražavalo na bilateralne odnose u celini.

Obe strane su uviđale i očiglednu korist koju je normalna politička komunikacija pružala nastavku sve razgranatije ekonomske saradnje iz prethodnih godina. Potreba za kontinuitetom i daljim unapređenjem privredne kooperacije bila je tim veća što ekonomski pokazatelji u obe zemlje nisu bili nimalo ružičasti. Jasno vidljivi indikatori su već ukazivali na sve veće tehnološko i privredno zaostajanje SSSR-a u odnosu na Zapad, što se neminovno odražavalo na spoljnopolitičku poziciju te zemlje. Jugoslovenska privreda se, takođe, posle neuspele reforme iz prethodnih godina, suočavala sa krupnim problemima. Mada su privredne teškoće $u$ obe zemlje bile posledica neefikasnog ekonomskog modela, fundiranog na državnom vlasništvu i regulativi, postojale su i bitne razlike prevashodno nastale kao rezultat veće otvorenosti jugoslovenske privrede prema svetu, posebno njene ekonomske saradnje sa zapadnim zemljama. Upravo je iz te razlike najvećim delom proistekla komplementarnost jugoslovenske i sovjetske privrede, koja je obe strane upućivala na što intenzivniju kooperaciju.

Imajući u vidu navedene razloge i okolnosti, Tito i jugoslovensko rukovodstvo su u jesen 1969, odmah posle posete Andreja Gromika, pristupili konkretnoj realizaciji namere da poboljšaju političke odnose sa SSSR-om. Važnu ulogu u tome trebalo je da odigra novi ambasador u Moskvi Veljko Mićunović, iskusan diplomata i političar, koji je tu funkciju već obavljao sredinom 50-ih. Smatralo se da bi on, budući da je poznavao mnoge ličnosti iz aktuelnog sovjetskog rukovodstva, mogao uspešno da obavi taj zadatak. S druge strane, za posta- 
vljanje na to mesto preporučivala ga je i okolnost da je bila reč o visoko rangiranom političaru (u tom trenutku, predsedniku spoljnopolitičkog odbora Savezne skupštine) koji je čvrsto zastupao Titov i Kardeljev koncept socijalizma i spoljne politike. Relativno brzo, međutim, ispostavilo se da takve procene nisu bile sasvim ispravne: posle nepune dve godine on je povučen - bilo je očigledno da je za obavljanje te funkcije $\mathrm{u}$ datim političkim koordinatama za tu poziciju bio potreban drugačiji tip diplomate. Inače, Mićunović je uoči odlaska u Moskvu od Tita dobio generalnu instrukciju koja je ukratko glasila: Jugoslavija ima interes i spremna je za poboljšanje odnosa sa SSSR-om i drugim socijalističkim zemljama ako to i oni žele, a jugoslovensko rukovodstvo ne menja politička gledišta u vezi sa Čehoslovačkom, što je Rusima vrlo dobro poznato. ${ }^{3}$

Odmah po dolasku u Moskvu, Mićunović je (sredinom decembra) tražio prijem kod Brežnjeva kome je trebalo da uruči Titov poziv da poseti Jugoslaviju. Dobio je odgovor da Brežnjev ne može da ga primi zbog prevelike zauzetosti, tako da je Titova poruka uz prilično kašnjenje prosleđena preko Ministarstva spoljnih poslova. ${ }^{4}$ U poruci Brežnjevu, Tito je konstatovao da je u poslednje vreme postignut napredak $\mathrm{i}$ da su otklonjene ,neke od prepreka“ $\mathrm{u}$ odnosima između dve zemlje, te da predsedništva SFRJ i SKJ smatraju kako je moguće unapređenje saradnje i „razvijanje stabilnih, ravnopravnih, prijateljskih odnosa“. Naglasivši da su obe strane pozitivno ocenile posetu Gromika Jugoslaviji, on je naveo da je jugoslovenska strana u cilju daljeg razvoja bilateralnih odnosa već dala više konkretnih predloga za saradnju u oblasti ekonomije, politike, informativne i kulturne delatnosti, „nekih pitanja“ vojne saradnje, obnove međupartijske i parlamentarne saradnje. Tito je ukazao i na pojave koje zabrinjavaju jugoslovensku stranu, posebno ,tendencija netačnog prikazivanja“ i umanjenja značaja „NOB-a i socijalističke revolucije naroda Jugoslavije“ od strane nekih sovjetskih istoričara i pisaca, zbog čega se stiče utisak da se iza toga „kriju određene političke tendencije“, kao i „pogrešne i nerealne ocene“ jugoslovenskog unutrašnjeg razvitka i samoupravnog sistema. Na kraju je poručio da bi jugoslovensko rukovodstvo sa zadovoljstvom prihvatilo ako bi Brežnjev kao i drugi najviši rukovodioci učinili

${ }^{3}$ V. Mićunović, Moskovske godine 1969/1971, Beograd 1984, 65-70. - Hladan odnos prema Mićunoviću zadržan je i kasnije: Brežnjev ga je prvi put primio tek februara 1971, a onda još jednom avgusta te godine, prilikom oproštajne posete pred povratak Mićunovića u Beograd. Bila je to velika razlika u odnosu na njegovo prvo službovanje u Moskvi kada je često razgovarao sa Hruščovom. Odnos prema Mićunoviću bio je u osnovi posledica toga što su u političkom kursu Moskve prema Jugoslaviji prevladavali pragmatični interesi, dok su u drugom planu bili ideološki sporovi i pretenzije da se suštinski izmeni jugoslovenski model socijalizma. Jugoslovenski ambasador im nije bio potreban kao partner za ideološke i političke rasprave, što je svojevremeno praktikovano u brojnim susretima Mićunovića sa Hruščovom i ostalim funkcionerima. Ne treba, naravno, u svemu tome zanemariti ni okolnosti na koje sam Mićunović ukazuje u svojim memoarima da mu tadašnje sovjetsko vođstvo nije oprostilo zbog njegovih bliskih veza i prijateljskih odnosa sa Hruščovom, kao i njegove vrlo kritične javne nastupe povodom vojne intervencije u Čehoslovačkoj.

$$
{ }^{4} \text { Isto, } 77-78 .
$$


posetu Jugoslaviji što bi bila prilika za razgovore o unapređenju saradnje, otvorenim pitanjima i aktuelnim međunarodnim problemima. ${ }^{5}$

Jugoslovensko-sovjetski odnosi su, i pored primetnog opreza i utvrđivanja pozicija, početkom 70 -ih krenuli u pravcu poboljšanja. Sovjetska strana je izrazila spremnost za intenziviranje industrijske kooperacije i vojne saradnje, a sovjetski ambasador Ivan Benediktov je u januaru 1970. preneo Titu pozitivan stav Brežnjeva povodom poziva da poseti Jugoslaviju i saglasnost sovjetskog rukovodstva sa stavovima o unapređenju saradnje iznetim u Titovoj poruci. ${ }^{6}$ Značajan impuls bilateralnoj saradnji trebalo je da pruži i poseta SSSR-u Mitje Ribičiča, predsednika SIV-a, čija je priprema bila u toku. Obe strane su nastojale da smanje ili eleminišu sporna pitanja koja su se negativno odražavala na odnose dve zemlje, a koja nisu bila od vitalne važnosti za njihove interese kao na primer: napisi i nastupi u jugoslovenskoj javnosti koje je Moskva ocenjivala kao antisovjetske, ograničavanje delatnosti informbirovske emigracije u SSSR-u, stara ideološka sporenja, razlike u pogledima na neka međunarodna pitanja i odnose između socijalističkih zemalja i komunističkih partija.

Tokom 1970, iako nije realizovana poseta Brežnjeva, ostvaren je značajan napredak u odnosima, o čemu svedoče i posete visokih zvaničnika dve strane, od kojih su najznačajnije bile posete SSSR-u Nikole Ljubičića, saveznog sekretara za narodnu odbranu (maj), Mitje Ribičiča, predsednika SIV-a (jun), kao i poseta delegacije Vrhovnog sovjeta SSSR-a Jugoslaviji (oktobar). Kako je službeno saopšteno u razgovorima jugoslovenske vladine delegacije koju je predvodio Ribičič sa Aleksejem Kosiginom, predsednikom sovjetske vlade, izražena je spremnost obe strane za dalji razvoj privredne, naučne, kulturne i drugih oblika saradnje. To je u suštini bio najvažniji rezultat ove posete i razgovora delegacija dve vlade na najvišem nivou (24-25. jun), ali se iz izveštaja o ovim razgovorima može zaključiti da su povremeno iskrsavale nesuglasice, pa i optužbe koje su svedočile o tome da i dalje postoje značajna razilaženja u pogledima na pojedina politička pitanja, o kojima su se dve strane i ranije sporile. Politička atmosfera još nije bila na neophodnom nivou za brži i kvalitetniji razvoj međusobne saradnje. U izveštaju Veljka Mićunovića navode se ocene i stavovi Alekseja Kosigina, koji se očigledno nisu dopadali jugoslovenskoj strani. Kosigin je, kako stoji u izveštaju, između ostalog bio veoma kritičan prema jugoslovenskoj spoljnoj politici: izjavio je da ni sam predsednik SIV-a ne veruje u sliku sveta i gledišta Jugoslavije na situaciju u svetu koju je izneo. Rekao je da je jugoslovenska politika idealistička i nerealna, a samim tim i neodrživa, tvrdeći da ,između dva postojeća bloka - nema laviranja“.7

${ }^{5}$ Arhiv Jugoslavije (AJ), Arhiv CKSKJ, IX, 119/I -396, Pismo Tita Brežnjevu, 7. decembar 1969.

${ }^{6}$ Arhiv Jugoslavije (AJ), Kabinet Predsednika Republike (KPR), 837, I -3-a/101-118, Beleška o razgovoru Tito-Benediktov, 23. januar 1970. - Sagovornici su se saglasili da bi do posete moglo doći kasnije tokom te godine.

${ }^{7}$ AJ, KPR, 837, I-5-b/99-23, Ocene o poseti predsednika SIV-a Mitje Ribičiča SSSR-u, 6. jul 1970. - Kasnije, na ručku, Kosigin je rekao da ne žali što je na pregovorima izrekao mnoge neprijatne stvari u pogledu politike Jugoslavije, jer to treba da se kaže ,prijateljima i drugovima“. 
Iz ovakvog nastupa Kosigina, Mićunović je izveo zaključak da je sovjetska vlada zadržala poznate rezerve prema spoljnoj politici Jugoslavije; da je sovjetsko rukovodstvo i dalje veoma osetljivo na jugoslovensku politiku prema zemljama socijalističkog lagera (da je Kosigin, više puta, posebno govorio o „destruktivnoj ulozi Jugoslavije u odnosu na soc. lager", jugoslovenskim stavovima povodom događaja u Čehoslovačkoj i dr.); da sovjetska vlada ne pridaje značaj jugoslovenskoj politici nesvrstavanje (sovjetsko rukovodstvo tu politiku ocenjuje kao obično brbljanje o miru, jedinstvu i progresu čitavog sveta, kao jugoslovensko manevrisanje između dva bloka radi dobijanja koristi za sebe od oba bloka); da sovjetska vlada ne pokazuje interes za rešenje krupnih bilateralnih pitanja između dve zemlje i da direktno uslovljava ekonomsku saradnju sa kvalitetom političkih odnosa i političkim poverenjem između dve zemlje (Kosigin je više puta stavio do znanja da će se SSSR i ubuduće tako odnositi prema Jugoslaviji). Mićunović je dodao i još neke ocene: da sovjetska strana ne gleda na Jugoslaviju kao ravnopravnog partnera već nastupa s pozicije jačeg, velikog, starijeg; da su došle do izražaja nepomirljive razlike između dve strane u pogledima na osnovne međunarodne i bilateralne probleme. ${ }^{8}$

Stvari se u praksi ipak nisu nisu odvijale nepovoljno u meri kako je to sugerisano u ovom, ali i u još nekim izveštajima Veljka Mićunovića i Ambasade u Moskvi. ${ }^{9}$ Kontakti i saradnja su tokom 1970, i pored nepovoljnih okolnosti iznetih u tim izveštajima, hvatali sve jači zamah. Sovjetski ambasador u Beogradu Ivan Benediktov je primetno intenzivirao svoje aktivnosti; vrlo često se sastajao sa funkcionerima MIP-a, ljudima zaduženim za međunarodnu partijsku saradnju i drugima, interesujući se za razna pitanja. Učestali su kontakti i susreti na kojima su produžavani ili sklapani novi aranžmani u oblasti robne razmene, vojne i drugih oblika saradnje, što je značilo da je u tom smislu dato odobrenje s političkog vrha u obe zemlje (obnovljena je i praksa razmene odlazaka na odmor partijskih funkcionera). Prilično tvrdi politički stavovi sovjetske strane (koji su bili predmet Mićunovićevih opservacija), a takvi stavove su u suštini zastupali Tito i jugoslovensko vođstvo o osnovnim postulatima jugoslovenske politike, bili su zapravo u službi zauzimanja i učvršćivanja osnovnih političkih pozicija pred otopljavanje i novi uspon međusobnih odnosa. Jedni drugima su poručivali da nema promena $u$ ključnim političkim stavovima i da je uslov napretka saradnje njihovo uvažavanje. Za sovjetsku stranu prioritetno je bilo da Tito i jugoslovenska vlada prihvate, ili barem ne izlažu kritici, sovjetsku poziciju i politiku u odnosima između socijalističkih zemalja i u međunarodnom komunističkom pokretu, kao i uopšte sovjetske stavove i nastup prema aktuelnim međunarodnim pitanjima. Za jugosloven-

${ }^{8}$ U zaključku izveštaja Mićunović navodi da su iznete ocene možda preterano pesimističke, ali da su on i ostali saradnici iz Ambasade osećali dužnost da iznesu svoje mišljenje i činjenice koje, po njima, ne ostavljaju mesta za veći optimizam, barem ne u dogledno vreme. - Isto.

${ }^{9}$ Slične, prilično pesimističke poglede i ocene o aktuelnom stanju i perspektivi jugoslovensko-sovjetskih odnosa iznete su i u godišnjem izveštaju za 1969, koji je Ambasada u Moskvi poslala 16. januara 1970. - AJ, KPR, 837, I-5-b/99-23. 
sku stranu je, pak, najvažnije bilo to da se u Moskvi uvažavaju međunarodni položaj Jugoslavije, specifičnost njenog socijalističkog uređenja i principi iz deklaracija o odnosima dve zemlje potpisanim sredinom 50-ih godina.

Mada tokom 1970. nije realizovana poseta Brežnjeva Jugoslaviji, politički dijalog Beograda i Moskve sve više je jačao i dobijao sve viši nivo, a taj trend se nastavio i u sledećoj godini. Početkom 1971. sve veću pažnju sovjetske strane zaokupljala je unutrašnja situacija u Jugoslaviji koju su, uz ekonomske teškoće, opterećivale pojačane nacionalne tenzije i separatističke težnje koje su kulminirale u proleće te godine u Hrvatskoj. Ambasador Benediktov je u januaru 1971, pred odlazak sa te dužnosti, u razgovorima sa visokim jugoslovenskim zvaničnicima nastojao da dobije što više informacija o unutrašnjim problemima u Jugoslaviji. U razgovoru sa Edvardom Kardeljom, drugim čovekom jugoslovenskog rukovodstva i glavnim kreatorom preustrojstva jugoslovenske federacije koje je bilo u toku (ustavni amandmani), Benediktov je izjavio da ne razume ,toliku galamu izvan i unutar Jugoslavije o njenom navodnom raspadanju“ (sovjetske diplomate su ovakvu formu pitanja kroz konstataciju da su nešto od drugih čuli ili pročitali u štampi često koristili). Kardelj je, uz ocenu da se tekući problemi predimenzioniraju i da on „ne vidi nikakvu katastrofu po jedinstvo Jugoslavije“, uveravao sagovornika da će kroz tekuće „korekcije“ odnosi između federalnih jedinica biti ,postavljeni na zdrave osnove“", da o tome „postoji jedinstveno gledište među zainteresovanim faktorima“, da će se sprovođenjem tih promena znatno suziti prostor za delovanje „neprijatelja socijalizma“ a da su to u stvari „razne nacionalističke snage koje stalno žele da našoj socijalističkoj demokratiji suprotstave demokratiju zapadnog, buržoaskog tipa“. Benediktov nije delio optimističke poglede koje je izneo Kardelj - izrazio je sumnju „neće li ustavne promene podstaći nacionalizam, a ne oslabiti ga“. Sagovornici su se, inače, saglasili o potrebi daljeg jačanja ekonomske saradnje i ukupnih odnosa između dve zemlje, pri čemu je Benediktov naglasio da je u tome glavno „da mi ne napadamo njihov sistem niti oni naš ${ }^{6} .10$

I prilikom oproštajne posete kod Tita, uz povoljne ocene o razvoju jugoslovensko-sovjetskih odnosa u poslednje vreme, bilo je reči o promenama u federalnom ustrojstvu i reorganizaciji najviših državnih organa. Tito je, kao i Kardelj, vrlo afirmativno govorio o tim promenama - da te mere ,imaju dalekosežni značaj za jačanje jugoslovenske socijalističke zajednice“, a na pitanje Benediktova nema li predsednik bojazan od mogućih negativnih reperkusija zbog dosta širokih prava koje republike dobijaju, on je eksplicitno izjavio da takvih bojazni nema i da, naprotiv, smatra „da je to jedini put daljeg jačanja Jugoslavije i jedinstva među našim narodima“". ${ }^{11}$ Opaske Benediktova izrečene u razgovorima sa najvišim

${ }^{10}$ AJ, KPR, 837, I-5-b/99-24, Zabeleška o razgovoru Kardelj-Benediktov, 26. januar 1971.

11 AJ, KPR, 837, I-3-a/101-122, Zabeleška o razgovoru Tito-Benediktov, 26. januar 1971. - Tito je i ovu priliku iskoristio da ukaže koliko bi bila značajna poseta Brežnjeva Jugoslaviji, budući da u međusobnim odnosima postoje pitanja „koja ipak smetaju“ i o kojima bi se otvoreno diskutovalo u razgovoru sa Brežnjevom radi otklanjanja raznih nesporazuma. 
jugoslovenskim rukovodiocima u vezi sa krupnim promenama u federalnom sistemu jasno pokazuju da se u Moskvi nije sa simpatijama gledalo na te promene, ali su se, u skladu sa zvanično prihvaćenim principom o nemešanju u unutrašnje stvari, sovjetski predstavnici u razgovorima sa jugoslovenskim zvaničnicima uzdržavali od izričitijih komentara ili ulaska u sporenje, ostajući uglavnom na indirektnom ukazivanju da o tome imaju različito mišljenje.

Povodom oproštajne posete Benediktova u jugoslovenskom MIP-u sačinjena je sažeta analiza o sovjetskoj unutrašnjoj i spoljnoj politici i stanju u jugoslovensko-sovjetskim odnosima. U pogledu situacije u SSSR-u konstatuje se da nema značajnijih pomaka u ekonomiji i nagoveštaja da se pripremaju dalekosežnije promene u smislu prevazilaženja dotadašnjeg načina upravljanja, te da razmišljanja pojedinih ekonomista o potrebi poštovanja ekonomskih zakonitosti nisu naišla na zvaničnu podršku. $\mathrm{Na}$,ideološkom frontu“ uočava se dalje zaoštravanje „ॅcime se još više sužavaju mogućnosti za slobodno ispoljavanje stvaralaštva $u$ nauci i umetnosti. U sovjetskoj spoljnoj politici nastavljaju se poznati strateški pravci: jačanje pozicije SSSR-a u lageru, u Evropi sporazum sa SR Nemačkom i pripreme za KEB, učvršćivanje pozicija na Srednjem istoku (posebno Egipat), a u odnosima sa SAD pregovori o razoružanju (SALT)." U vezi sa bilateralnim odnosima, navodi se da se u sovjetskom stavu prema Jugoslaviji i dalje održavaju rezerve u pogledu njene unutrašnje politike kao i prema nesvrstanoj spoljnoj politici i da takav odnos prema jugoslovenskoj politici, zajedno sa izražavanjem spremnosti za razvoj saradnje u određenim oblastima, rezultira oscilacijama i neravnomernostima u bilateralnoj saradnji. Na polju političke saradnje, osnovni problem za jugoslovensku stranu bio je u tome što se u Moskvi uporno održavala atmosfera rezervisanosti i neizvesnosti, zbog čega je bilo znatno manje poseta na visokom nivou sa sovjetske strane i stalno je odlagana poseta Leonida Brežnjeva. Najpozitivnija strana u odnosima dve zemlje, kako je označeno u materijalu, bila je ekonomska saradnja. Obim trgovinske razmene povećan je 1970. za 15\% u odnosu na prethodnu godinu (SSSR je bio na trećem mestu kao trgovinski partner Jugoslavije, posle SR Nemačke i Italije), i to ne računajući vojne isporuke, a u toku su bili pregovori o zaključenju sporazuma o robnoj razmeni za period 19711975. godine. ${ }^{12}$

U sovjetskom vrhu je, po svemu sudeći, početkom 1971. zauzet stav da se intenzivira politički dijalog na visokom nivou i uopšte bilateralna saradnja sa Jugoslavijom. Veljka Mićunovića je početkom februara, petnaest meseci po stupanju na dužnost ambasadora, primio i Leonid Brežnjev. Brežnjev je tom prilikom rekao da su on lično, kao i Politbiro, imali pozitivan stav o njegovoj poseti Jugoslaviji i susretu sa Titom, ali da se to nije moglo ostvariti zbog njegovog lošeg zdravstvenog stanja tokom protekle godine. Sovjetski lider je rekao da će vrlo rado doći u Jugoslaviju prvom prilikom posle partijskog kongresa koji je u

${ }^{12}$ AJ, KPR, 837, I-3-a/101-122, Analiza sačinjena na bazi informacija DSIP-a, 22. januar 1971. 
to vreme bio u pripremi, kada to i Titu bude odgovaralo. On se u potpunosti složio sa Titovim gledištima o daljem unapređenju jugoslovensko-sovjetskih odnosa iznetim u pismu koje mu je Mićunović tada uručio. Govorio je i o razlikama između unutrašnjih sistema, uveravajući sagovornika da niko u sovjetskom vrhu ne smatra da Jugoslovenima treba davati savete u tom pogledu, a da će sam narod najbolje oceniti sistem samoupravljanja na osnovu rezultata; da je on s rezervom primao obrazloženja o tom sistemu, ali da ga nije kritikovao jer to nije njegov posao. Brežnjev je pokazao interes za unapređenje ekonomske i vojne saradnje između dve zemlje, obećavši da će intervenisati kod pregovarača sa sovjetske strane $u$ vezi sa sklapanjem novog trgovinskog ugovora oko čega su postojale teškoće. Bio je, međutim, vrlo kritičan prema pisanju jugoslovenske štampe i objavljivanju pojedinih knjiga (naveo je memoare Karla Štajnera 7000 dana u Sibiru i nameru objavljivanja memoara Nikite Hruščova), ocenivši da napisi u jugoslovenskoj štampi i publikacije u kojima se negativno piše o SSSR-u nepovoljno utiču na odnose dve zemlje, a da sovjetsko rukovodstvo želi najbolje odnose sa Jugoslavijom. Osim ovoga, Brežnjev nije pokretao pitanja oko kojih su postojale razlike i sporenja, niti je otvarao diskusiju o unutrašnjim problemima u Jugoslaviji ili o spoljnopolitičkim pitanjima o kojima su Moskva i Beograd imali različite poglede. Jedino je povodom najavljene uzvratne posete Tita SAD (Ričard Nikson je bio u poseti Jugoslaviji od 30. septembra do 2. oktobra 1970) za koju još nije bio određen termin (realizovana oktobra 1971), uz ogradu da je to njegovo lično mišljenje, prokomentarisao da se u okolnostima kada Nikson nastavlja rat u Indokini i podržava Izrael protiv Arapa ta poseta može različito tumačiti u raznim državama, ali da je to isključivo stvar jugoslovenskog rukovodstva. ${ }^{13}$

Da je intenzivirana komunikacija, pa i poboljšana atmosfera u političkom dijalogu Beograda i Moskve tokom proleća 1971, svedoče i neki postupci sovjetskog vođstva, kakvi se samo malo ranije nisu preduzimali niti su bili očekivani. Tako je Leonid Brežnjev telefonirao Titu 30. aprila, dok je još bila u toku sednica Predsedništva SKJ na Brionima na kojoj se diskutovalo o političkim tenzijama u zemlji izazvanim eskalacijom hrvatskog separatizma. Prema informaciji upućenoj iz Beograda Veljku Mićunoviću povodom toga, Brežnjev je interesujući se za navodne pokrete trupa i unutrašnju situaciju koju je okvalifikovao kao „očenj važnuju“ (,vrlo važnom“ - citat u informaciji) po svemu sudeći nagovestio sovjetsku spremnost da pruži pomoć, što se može zaključiti iz navođenja Titovog odgovora da su informacije o pokretu trupa lažne, da jugoslovensko rukovodstvo ima dovoljno snage da samo reši probleme sa kojima se suočava, bez ikakve pomoći bilo koga. Brežnjev je na to uzvratio da pozdravlja energičnost jugoslovenskog rukovodstva ,da se svim neprijateljima socijalizma da pravilan odgovor". 14

${ }^{13}$ V. Mićunović, $n . d, 117-125$.

${ }^{14}$ AJ, KPR, 837, I-5-b/99(24-28), Informacija za V. Mićunovića o telefonskom razgovoru Brežnjeva i Tita 30. aprila 1971. -Informacija je sačinjena 28. maja, skoro mesec dana posle ovog događaja, i to na traženje Mićunovića, koji je za taj telefonski razgovoru između dva lidera 
Još jedan korak sovjetske strane iz tog perioda predstavljao je iskušenje za dalji tok političke komunikacije između Beograda i Moskve. Naime, sovjetska vlada je 26. maja 1971. uputila molbu jugoslovenskoj vladi da dozvoli prelet preko jugoslovenske teritorije u pravcu Sredozemlja sedam parova sovjetskih vojnih aviona. Kao cilj leta navedena je „obuka pilota i razrada koordinacije i sadejstva sa flotom baziranom u Sredozemnom moru“. Uz izražavanje uverenja da će jugoslovenska vlada pozitivno odgovoriti, u molbi je navedeno da bi se letovi obavili tokom nekoliko dana sredinom juna tekuće godine. ${ }^{15} \mathrm{U}$ Ministarstvu spoljnih poslova 9. juna saopšteno je sovjetskom ambasadoru Vladimiru Stepakovu da je molba sovjetske vlade neprihvatljiva za jugoslovensku stranu. U obrazloženju je navedeno da bi prelet aviona u navedene svrhe bio nespojiv sa nezavisnošću SFR Jugoslavije, njenom nesvrstanom politikom i ustavom, da bi to bilo $\mathrm{u}$ suprotnosti sa nastojanjima jugoslovenske vlade za daljim popuštanjem zategnutosti u Evropi, na Balkanu i Sredozemlju, te da jugoslovenska vlada ne želi da čini korake koji bi na bilo koji način proširivali vojne aktivnosti na ovom prostoru. ${ }^{16}$

Zašto je u Moskvi odlučeno da se jugoslovenskoj vladi uputi ovakva molba i pored toga što su jugoslovenska međunarodna pozicija i njeni spoljnopolitički principi i stavovi bili vrlo dobro poznati i što se, imajući to vidu, mogao očekivati negativan odgovor? Čini se verovatnim da je sovjetska procena bila da bi jugoslovensko vođstvo, s obzirom na unutrašnje političke probleme sa kojima se suočavalo, moglo da prihvati takvu molbu; a ukoliko bi se jednom napravio takav presedan, onda bi se i u buduće moglo računati na korišćenje jugoslovenske teritorije radi postizanja efikasnijeg i snažnijeg nastupa u regionu Mediterana i Bliskog istoka gde je sovjetski angažman poslednjih godina bio sve vidljiviji. Bio je to, istovremeno, i način da se ispita do koje mere su Tito i jugoslovensko rukovodstvo spremni da izađu u susret njihovim zahtevima, odnosno da li bi novo zbližavanje sa Jugoslavijom moglo doneti praktične koristi, prvenstveno u ostvarivanju određenih spoljnopolitičkih ciljeva. Mada se jugoslovenskoj strani nisu dopadali ovakvi potezi Moskve, to nije dovelo do oštrijih reakcija niti je izazvalo povećanu sumnju u opredeljenje za nastavak poboljšanja političkih odnosa sa SSSR-om. Tito i jugoslovensko vođstvo su bili sigurni u postojanost međunarodne pozicije Jugoslavije, čemu je dodatnu garanciju pružala okolnost da su upravo u to vreme politički odnosi sa SAD bili na izuzetno visokom nivou, tako da su u politički dijalog sa Moskvom ulazili sa priličnim samopouzdanjem i čvrstinom u pogledu zastupanja principa na kojima su se temeljili međunarodni položaj zemlje i odnosi sa SSSR-om.

čuo od D. Poljanskog, prvog zamenika premijera sovjetske vlade i člana Politbiroa, u razgovoru na prijemu u kanadskoj ambasadi 19. maja 1971. - V. Mićunović, $n$. d, 129-130.

${ }^{15}$ AJ, KPR, 837, I-5-b/99-24, Zabeleška razgovora Jakše Petrića, zamenika državnog sekretara za spoljne poslove i Vladimira Stepakova, sovjetskog ambasadora, 26. maj 1971.

${ }^{16}$ AJ, KPR, 837, I-5-b/99(24-28), Zabeleška razgovora Đ. Vukolića, načelnika Uprave za istočnu Evropu DSIP sa V. Stepakovim, 9. jun 1971. 
Poseta Leonida Brežnjeva (poziv dobio još krajem 1969) bila je ključni događaj koji je trebalo da definitivno označi obnovu političkog dijaloga Beograda i Moskve na najvišem nivou. Krajem juna 1971, sovjetska strana je konačno saopštila pozitivan odgovor u vezi sa posetom Brežnjeva sa predlogom da se realizuje krajem septembra tekuće godine. ${ }^{17} \mathrm{U}$ razgovoru sa ambasadorom Stepakovom 8. jula, Tito je rekao da bi bilo dobro da do posete Brežnjeva dođe pre nego što on poseti SAD na poziv Niksona ${ }^{18}$ Sredinom avgusta, Titu je prenet predlog Brežnjeva da u posetu Jugoslaviji u trajanju od tri-četiri dana dođe 22. septembra. ${ }^{19}$ Neposredno pred posetu, Stepakov je uručio Titu predlog Brežnjeva o tekstu zajedničke izjave o jugoslovensko-sovjetskim odnosima, u vezi s čim je Tito naglasio da su principi na kojima se zasnivaju odnosi između dve zemlje već ranije zajednički utvrđeni i da jugoslovenska strana od njih ne želi nikako da odstupi, ali da je na bazi tih principa spremna da još više unapređuje međusobnu saradnju. ${ }^{20}$

Brežnjev je dosta opširno govorio o predstojećoj poseti Jugoslaviji, ali i o drugim pitanjima prilikom oproštajnog prijema Veljka Mićunovića 10. avgusta 1971. On je ponovio da sovjetsko rukovodstvo i on lično žele najbolje odnose sa Jugoslavijom; svako ide svojim putem i sistemi su različiti, ali Jugosloveni ne mogu skrenuti Sovjete sa njihovog puta, a ni oni ne žele da Jugoslaviju skrenu sa puta kojim ide. Brežnjev, kako je izjavio, stoga ne vidi razlog za sukobljavanje. Povodom žalbi jugoslovenske strane na delovanje informbirovske emigracije $u$ SSSR-u, ocenio je da oni nisu značajni (samo ih je oko 300) i da ih vlasti ne podstiču. Izneo je sovjetske poglede na međunarodnu situaciju i stavove SSSR-a prema Kini, SAD, SR Nemačkoj, konferenciji o evropskoj bezbednosti, odnosima u socijalističkom bloku, kao i o „doktrini Brežnjeva“ - negirajući postojanje takve doktrine. Brežnjev je, ,govoreći kao prijatelj“, rekao da su oni duže vreme bili zabrinuti zbog događanja u Jugoslaviji i da, iako je to unutrašnja stvar Jugoslavije, njih kao prijatelje to mora da interesuje. Navodeći kao krupne probleme nezaposlenost $\mathrm{i}$ odliv radnika i stručnjaka na Zapad, on je kao najteži problem istakao javne političke sukobe između jugoslovenskih republika i nacija, uz zaključak da, bez obzira šta o tome mislili na sovjetskoj ili jugoslovenskoj strani, ostaje činjenica „da su u Jugoslaviji dopušteni ozbiljni propusti (on neće da kaže krupne greške) jer inače do ovoga kod Vas ne bi došlo". ${ }^{21}$ I od drugih članova sovjetskog vođstva jugoslovenska strana je dobijala uverenja da su oni oprede-

${ }^{17}$ Istovremeno sa odgovorom o svojoj poseti, Brežnjev je pozvao Tita da dođe na odmor na Krim i da tamo neformalno razgovaraju. Tito je, međutim, odgovorio da zbog prezauzetosti nije u mogućnosti da prihvati poziv. - AJ, KPR, 837, I-3-a/101-124, Zabeleška o razgovoru Tita sa Dimitrijem Sevjanom, otpravnikom poslova sovjetske Ambasade, 24. jun 1971.

${ }^{18}$ AJ, KPR, 837, I-3-a/101-128, Zabeleška o razgovoru Tito-Stepakov, 8. jul 1971.

${ }^{19}$ AJ, KPR, 837, I-3-a/101-129, Zabeleška o razgovoru Tito-Sevjan, 17. avgust 1971.

${ }^{20}$ AJ, KPR, 837, I-3-a/101-130, Zabeleška o razgovoru Tito-Stepakov, 16. septembar 1971.

${ }^{21}$ Izveštaji V. Mićunovića od 12. i 13. avgusta 1971, AJ, KPR, 837, I-3-a/101-131; V. Mićunović, $n . d, 133-140$. 
ljeni za razvoj svestrane saradnje sa Jugoslavijom i da sa takvim stavom i uverenjem Brežnjev ide u Jugoslaviju da razgovara sa Titom i jugoslovenskim rukovodstvom. ${ }^{22}$

U razgovorima Brežnjeva i Tita (u četiri oka i na zajedničkim sastancima dve delegacije) tokom posete sovjetskog lidera Jugoslaviji (22-25. septembar) razmatrane su, osim odnosa Jugoslavije i SSSR-a, i druge najaktuelnije teme spoljne i unutrašnje politike dveju zemalja. Brežnjev je istakao da svako ide svojim putem u izgradnji socijalizma a međudržavne odnose je ocenio normalnim, $s$ napomenom da bi mogli biti i znatno bolji i da po državnoj liniji nema ničeg naročitog što bi bilo predmet razdora i nesuglasica. Sovjetska strana želi dobre međupartijske odnose, kao i saradnju u ekonomiji i drugim oblastima - istakao je Brežnjev. Ono što je najviše kritikovao bilo je - kao što su to on i drugi sovjetski zvaničnici činili i ranije - pisanje jugoslovenske štampe i publicistike. S timu vezi Brežnjev je kazao: „Nedavno sam čitao neki antisovjetski članak. Niko ne osporava da je Jugoslavija izabrala put, nekakav, ne znam kako da ga nazovem ne mogu da se setim - samoupravljanje“. Štampu i propagandu je optužio da su glavni „,centar pogoršanja odnosa“, založivši se za razvoj prijateljstva između dve zemlje i osnivanje društava jugoslovensko-sovjetskog prijateljstva preko kojih bi se razvijale veze i organizovali susreti i saradnja. Demantovao je sovjetsko mešanje u unutrašnje stvari Jugoslavije, tražeći da se se za to navede neki primer. Brežnjev je tim povodom izjavio da je čuo da „neke snage nastoje da rašire osećaj straha od Sovjetskog Saveza“, dodavši: „Ja nisam nikada bio uzbuđeniji nego onda kada sam čuo da u Jugoslaviji misle da Sovjetski Savez misli da napadne Jugoslaviju“. ${ }^{23}$

Tito se u svom izlaganju, osim apela da se zajednički rešavaju problemi i razvijaju dobri odnosi između Jugoslavije i SSSR-a, najviše zadržao na unutrašnjim pitanjima u Jugoslaviji. Najbitnije u tom izlaganju bilo je sledeće: Razni neprijatelji socijalizma su „digli glavu“ i uzeli nacionalizam i šovinizam kao osnovnu bazu za napad i to kod svih. Hrvatski šovinisti su ubili ambasadora (Vladimira Rolovića, ambasadora u Švedskoj, ubijen aprila 1971); gore fabrike, gore šume u Dalmaciji, ne znamo da li slučajno ili ne, ali šteta je ogromna. Pojavili se svi mogući negativni elementi. Počelo se govoriti „da sam ja koji držim skupa - jadna zemlja koju jedan čovek može da drži.“" Amandmani na ustav idu dobro, kao i reforma organa federacije, a glavna snaga u svemu tome je SK. O ekonomskoj situaciji su opširno govorili drugi članovi jugoslovenske delegacije. $^{24}$

${ }^{22}$ Ovakve stavove izneo je i Nikolaj Podgorni, predsednik Prezidijuma Vrhovnog sovjeta SSSR-a, prilikom predaje akreditiva Milorada Pešića, novog jugoslovenskog ambasadora u Moskvi, 20. septembar 1971. - AJ, KPR, 837, I-5-b/99-24. tembra 1971 .

${ }^{3}$ AJ, KPR, 837, I-3-a/101-131, Stenografske beleške razgovora Tito-Brežnjev 23. sep-

${ }^{24}$ Isto. - Stenografske beleške razgovora Tito-Brežnjev 24. septembra 1971. 
U razgovorima u četiri oka koje su Tito i Brežnjev imali tokom posete izneti su detalji i pojašnjenja pozicija koji su davali potpuniju sliku o pogledima dvojice lidera na odnose između dve zemlje i međunarodna pitanja. O tim susretima, kao i uopšte o razgovorima dve delegacije i ocenama posete Leonida Brežnjeva, Tito je govorio na proširenoj sednici Izvršnog biroa Predsedništva SKJ, 3. oktobra 1971. godine. Brežnjev je, prema onome što je Tito izneo, posebno insistirao na tome da Sovjetski Savez nikada nije imao nameru da napadne Jugoslaviju i „bio jako ogorčen“ („,mnogo ogorčeniji“ nego na zajedničkoj sednici) zbog toga što im se prebacuje da je održavanje njihovih manevara oko jugoslovenskih granica imalo za cilj pritisak na Jugoslaviju, odnosno pripreme nekog napada na Jugoslaviju. S tim u vezi, Tito je citirao reči Brežnjeva: ,Ja sam spreman da žrtvujem i porodicu i sebe ako bi do takvog nečega moglo doći. Prije sam spreman da žrtvujem sve što mi je najdraže nego da do toga dođe. To je apsolutno nemoguće." Ono što je Brežnjev razgovorom u četiri oka posebno hteo da postigne bilo je, prema Titovom mišljenju, da ga uveri u potrebu stvaranja društava prijateljstava između SSSR-a i Jugoslavije, ali da on to nije prihvatio uz obrazloženje da je bolje da se prijateljstvo gradi ,na svakodnevnoj praksi, na bilateralnim odnosima koji bi bili mnogo čvršći od nekih društava koja mogu više da smetaju nego koriste uzajamnoj saradnji. ${ }^{25}$

Tito je ocenio da je Brežnjev došao „sa dobro promišljenim stavovima“ u pogledu odnosa sa Jugoslavijom - ,videlo se da su oni o tome i ranije diskutira1i“. Brežnjev je prvi postavio pitanje principa iz 1955, to jest da oni i dalje važe i bio za to da se oni unesu u zajedničke dokumente o poseti i razgovorima (kominike o poseti i izjava o odnosima dve zemlje) i prvi put je ,,izrazio izvesno priznanje nesvrstanosti Jugoslavije i, uz Jugoslaviju, nesvrstanima“, s tim što bi želeli da Jugoslavija svoj prestiž među nesvrstanima na neki način koristi „u pravcu podrške politici Sovjetskog Saveza“. Iz ovoga, kao i drugih elemenata iz Brežnjevog nastupa Tito je izneo utisak da je njima „mnogo stalo do dobrih odnosa sa Jugoslavijom“. ${ }^{26}$

Brežnjev je u razgovorima sa Titom u četiri oka izneo i neke aspekte sovjetske spoljnopolitičke orijentacije i poglede na međunarodne odnose koji se nisu mogli čuti u javnim nastupima sovjetskih zvaničnika. Obrazlažući potrebu da se postepeno i uz sporazumevanje priprema konferencija o evropskoj bezbednosti, on je izneo mišljenje da pitanje evropske bezbednosti „,ne može dati rezultate ako se ne pristupi, odnosno ako se jasno ne kaže da treba likvidirati oba bloka, tj. i Atlantski i Varšavski, u prvom redu njihov vojni karakter.“ Rešavanje

${ }^{25}$ AJ, KPR, 837, I-3-a/101, Izlaganje J. B. Tita na proširenoj sednici Izvršnog biroa Predsedništva SKJ, oktobar 1971. - Tito navodi da je Brežnjev na zajedničkom sastanku „bio vrlo ogorčen, sa suzama u očima, udario šakom i rekao da je strašna stvar da mi u to verujemo, to jest da Sovjetski Savez može da napadne na nas, da ugrozi našu nezavisnost itd.“.

${ }^{26}$ Najviše polemika bilo je o pisanju štampe i informbirovcima u SSSR-u, ali Tito je to smatrao da su to sitne stvari koje ne utiču bitnije na kvalitet jugoslovensko-sovjetskih odnosa. Isto. 
pitanja evropske bezbednosti je, kako je smatrao Brežnjev, jedna od najvažnijih stvari, jer bi to imalo snažan odjek i omogućilo bi lakše rešavanje kriznih situacija na Dalekom i Bliskom istoku. Brežnjev se založio za rešenje sukoba na Dalekom i Bliskom istoku (o tome je govorio i na zajedničkom sastanku), ističući da bi to bilo u interesu SSSR-a jer oni imaju „strahovito velike izdatke“ za održavanje borbene gotovosti Severnog i Južnog Vijetnama, ali ih ogromno koštaju i Bliski istok i Kuba. Prema tome, rekao je Brežnjev, „mi zbilja iskreno želimo da dođe do neke solucije, do rešenja tih problema." U odvojenim susretima sa Titom sovjetski vođa je tražio da on u razgovoru sa Ričardom Niksonom prilikom predstojeće posete SAD ukaže na neophodnost postizanja sporazuma na Bliskom i Dalekom istoku, da može da kaže da su o tome ovde razgovarali, te da „može slobodno da mu kaže da Sovjetski Savez ne želi rat" i da ,želi dobre prijateljske odnose sa Amerikom“ (ovo je nekoliko puta ponovio). Brežnjev je dodao kako zna da Tito otvoreno govori sa Niksonom i da će mu to kazati, napomenuvši da to ,ne bi trebalo da ispadne kao da sam ti ja sugerisao da govoriš o tome““. ${ }^{27}$

Iz ovakvog nastupa Brežnjeva, Tito je na ovom sastanku jugoslovenskog rukovodstva izneo utisak da je ,Sovjetski Savez sada čvrsto rešen da na neki način dođe do preloma u odnosima između Istoka i Zapada“. Posebno je naglasio da je Brežnjev postavio pitanje likvidacije blokova: „To je krupna stvar. Nikada do sada to oni nisu govorili“‘. I dolazak Brežnjeva u Jugoslaviju, Tito je u završnoj oceni doveo u direktnu vezu sa razmišljanjima u Moskvi o promeni njihove spoljne politike, njihove potrebe „da se likvidiraju krizne situacije u pojedinim zemljama“. Najviše zbog toga im je stalo da poboljšaju odnose sa Jugoslavijom, kazao je Tito, ,jer bi im loši odnosi sa našom zemljom smetali, naročito u njihovim akcijama na evropskom području, kao što su pitanja bezbednosti i poboljšanje odnosa sa Zapadnom Evropom“. Dolaskom Brežnjeva u Jugoslaviju „likvidirane su razne špekulacije vani na račun odnosa između naše zemlje i Sovjetskog Saveza“ i njegova poseta je „,doprinela i smirivanju duhova“ u Jugoslaviji - ocenio je Tito. ${ }^{28}$

Ričardu Niksonu Tito je preneo poruke Leonida Brežnjeva (ne spominjući, naravno, da mu je to Brežnjev sugerisao). Prema Titovom izveštaju o poseti SAD, Niksona je „malo začudilo“ kad mu je rekao da je iz razgovora sa Brežnjevom primetio kako sovjetsko vođstvo želi uspostavljanje dobrih odnosa sa Amerikom, te da je on na pitanje Niksona šta misli zašto su oni postali fleksibilni odgovorio kako ne bi hteo da bude prorok, ali da na to gleda čisto realistički na osnovu onoga što mu je Brežnjev govorio „kako Sovjetski Savez ima strahovite izdatke na raznim mestima u inostranstvu“, a „da su oni čvrsto rešili da idu na podizanje standarda unutra““ ${ }^{29}$ Prema zapisniku o razgovoru Niksona i Tita na

\footnotetext{
27 Isto.

28 Isto.

${ }^{29}$ Izveštaj o poseti Tita SAD, Kanadi i Velikoj Britaniji na sednici Predsedništva SFRJ $i$ SIV-a, 19. novembar 1971 (stenografske beleške) - AJ, KPR, 837, I-2/50.
} 
sastanku od 30. oktobra 1971, Tito je rekao kako je bio iznenađen kada „mu je Brežnjev kazao da, ukoliko bi u Evropi bila postignuta takva bezbednost koja bi značila stabilizaciju prilika na tom kontinentu, onda bi se Sovjetski Savez saglasio sa ukidanjem oba bloka“. Nikson, veoma skeptičan u vezi s tim, izjavio je kako je „duboko uveren da sa stanovišta svojih sopstvenih interesa, Sovjeti ne mogu tolerisati nikakvu podelu ni nezavisnost unutar svog bloka“ “. ${ }^{30} \mathrm{I} \mathrm{u} \mathrm{razgovo-}$ ru sa britanskim premijerom Edvardom Hitom 8. novembra 1971, prilikom posete Velikoj Britaniji, Tito je ponovio svoje utiske iz razgovora sa Brežnjevom - o većoj fleksibilnosti u njegovim stavovima, o pozitivnom odnosu prema principima iz 1955/56. na kojima se zasnivaju jugoslovensko-sovjetski odnosi, KEB-u i mogućnosti raspuštanja blokova, želji za boljim odnosima sa SAD, o materijalnom teretu koji ima SSSR u podržavanju nekih svojih partnera u svetu. Hit je na to, slično Niksonu, reagovao uzdržano i sa nepoverenjem: da su Sovjeti ponekad čvrsti, ponekad fleksibilni, ali da im ,izgleda ciljevi ostaju isti““ i da su spremni „da upotrebe silu, ako treba, da svim sredstvima obezbeđuju svoje pozicije“. ${ }^{31}$

Jugoslovenska strana je, kao što se može videti iz Titovog izlaganja na sednici partijskog rukovodstva, bila veoma zadovoljna rezultatima posete Leonida Brežnjeva. Na prvom mestu zbog činjenice da su u razgovorima sa Brežnjevom i sovjetskom delegacijom, što je zatim objavljeno i u zajedničkim dokumentima povodom posete, reafirmisani principi o međusobnim odnosima iz Beogradske i Moskovske deklaracije koji treba da se zasnivaju na poštovanju ravnopravnosti, nemešanja u unutrašnje stvari, pravu na vlastiti model socijalističkog uređenja. ${ }^{32}$ Za Tita i jugoslovensko vođstvo bilo je takođe vrlo važno da su od Brežnjeva čuli čvrsta uveravanja kako se u Moskvi nikada nije razmišljalo niti razmišlja o mogućnosti napada na Jugoslaviji, čime su u najvećoj meri otklonjena podozrenja u Jugoslaviji i spekulacije u svetu koje su u tom smislu postojale u prethodne dve-tri godine. Od velikog značaja za jugoslovensku stranu, budući da je SSSR bio jedan od najvažnijih spoljnotrgovinskih partnera Jugoslavije, bilo je $i$ to što je na najvišem političkom nivou dat snažan podsticaj daljem unapređenju ekonomske saradnje dve zemlje. Sam čin posete Leonida Brežnjeva, vodećeg sovjetskog lidera, kao i njeni rezultati predstavljali su krupan doprinos učvršćenju međunarodne pozicije Jugoslavije - u potpunosti je, posle tri godine, uspostavljen balans u odnosima sa dve supersile, sa Istokom i Zapadom, što je bio temelj Titove spoljnopolitičke doktrine još od sredine 50-ih godina. A učvršćivanje međunarodnog položaja, koje je početkom 70 -ih godina Tito uspešno obavio, direktno se odražavalo na stabilizaciju političkih prilika u Jugoslaviji, odnosno

${ }^{30}$ AJ, KPR, 837, I-2/50/1, Zapisnik o razgovoru Nikson-Tito u Vašingtonu, 30. oktobar 1971 (prevod zapisnika Bele kuće) - Tito je rekao da, iako je Nikson u pravu kad kaže da Sovjeti neće nikada dozvoliti tim zemljama da napuste njihovu orbitu, ali da se oni malo po malo prilagođavaju promenama.

${ }^{31}$ AJ, KPR, 837, I-2/50/, Zabeleška o razgovoru Hit-Tito u Londonu, 8. novembar 1971.

${ }^{32}$ Politika, 26. septembar 1971. - Kominike o poseti i zajednička izjava o odnosima između dve zemlje. 
omogućavalo je Titu i njegovim saradnicima da se efikasnije obračunaju sa narastajućim političkim protivnicima, raznim „,neprijateljima socijalizma“, a onda i da sprovedu promene federativnog ustrojstva, političkog sistema sa naglašenim jačanjem uloge SKJ, kao i novog modela organizovanja i funkcionisanja u privredi i društvenim delatnostima.

I sovjetska strana je pozitivno ocenjivala rezultate posete Leonida Brežnjeva Jugoslaviji. Uspostavljanjem dobrih odnosa sa Jugoslavijom i stabilne političke komunikacije sa njenim rukovodstvom, značajno su ojačane pozicije SSSR-a na Balkanu, što je za Moskvu bilo veoma važno pogotovo zato što je, pored inače snažnog prisustva i uticaja SAD i Zapada, bilo sve uočljivije nastojanje Kine da pojača svoje prisustvo u ovom regionu. ${ }^{33}$ Pored toga računalo se da će se ubuduće moći više uticati na stavove Jugoslavije prema KEB-u, na njenu politiku u pokretu nesvrstanih, ali i na njenu posredničku ulogu prema Zapadu, naročito SAD. Naravno, i za sovjetsku stranu je bilo značajno unapređenje privredne saradnje sa Jugoslavijom, tim pre što je Sovjetski Savez bio suočen sa sve ozbiljnijim ekonomskim teškoćama kao i oštrim trgovinskim restrikcijama od strane Zapada.

Ovom za jugoslovensko-sovjetske odnose veoma važnom i uspešnom posetom uspostavljena je praksa kontinuiranog političkog dijaloga između Beograda i Moskve na najvišem nivou koja se, uprkos sporadičnih sporova i zahlađenja, nastavila tokom cele te decenije - do smrti njenih glavnih protagonista Tita i Brežnjeva (1980, odnosno 1982). U naredne dve godine, juna 1972. i novembra 1973, Tito je dva puta odlazio u posete SSSR-u, a posete su razmenili i predsednice dveju vlada Džemal Bijedić (1972) i Aleksej Kosigin (1973). Visok nivo političke komunikacije pozitivno se odražavao na proširivanje bilateralne saradnje na svim poljima. U susretima sa najvišim sovjetskim rukovodiocima tokom ove dve Titove posete nije bilo bitno novih momenata, jer su uglavnom sva važnija pitanja koja su predstavljala prepreke razvoju dobrih odnosa između dve zemlje bila na obostrano zadovoljavajući način razrešena ili u značajnoj meri relativizovana prilikom posete Brežnjeva. U sferi međusobnih odnosa konstatovan je napredak saradnje u prethodnom periodu i isticana je spremnost za još uspešniju kooperaciju u budućnosti. Posete su protekle u prijateljskoj atmosferi, a $\mathrm{u}$ razgovorima obe strane su pokazivale elastičnost i konstruktivnost $\mathrm{u}$ rešavanju problema iz bilateralnih odnosa. ${ }^{34}$

${ }^{33}$ U brojnim komentarima zapadne štampe i novinskih agencija upravo je procena sovjetskog rukovodstva da Kina - koja se sve više otvarala prema svetu i već preduzimala konkretne korake u uspostavljanju i jačanju veza sa balkanskim zemljama (Albanijom, Rumunijom, Jugoslavijom), predstavlja ozbiljnu pretnju sovjetskim interesima u ovom regionu bio jedan od glavnih motiva za dolazak Brežnjeva u Beograd.

${ }^{34}$ U zajedničkom kominikeu po završetku Titove posete SSSR-u, 5-10. juna 1972, kaže se, između ostalog, da su razgovori između J. B. Tita i L. Brežnjeva i N. Podgornog protekli „,u srdačnoj, otvorenoj i prijateljskoj atmosferi“. Posetu je pratio veliki publicitet u domaćoj javnosti, Titu je dodeljen najveći sovjetski orden - Orden Lenjina, a imao je i više javnih nastupa i govora. AJ, KPR, 837, I-2/53. - Materijal o poseti Tita SSSR-u, jun 1972. 
U diskusijama prilikom ovih susreta nisu bitnije umanjene razlike u gledištima na neka ideološka i spoljnopolitička pitanja, što se nije moglo ni očekivati s obzirom da su one nastale mnogo ranije i bile plod različitih modela socijalističkog uređenja i međunarodnog položaja, ali se na njima nije insistiralo, niti su isticane kao smetnja za razvijanje dobrih odnosa i saradnje. Isto tako ni razlike u stavovima o delovanju informbirovaca u SSSR-u i pisanju jugoslovenske štampe, o čemu je u svim ovim prilikama vođena rasprava, nisu remetile pozitivnu atmosferu u kojoj su se odvijale ove Titove posete i razgovori lidera dveju zemalja. Intenzivan politički dijalog na vrhu povoljno je delovao na saradnju dve zemlje tokom 1972. i 1973. godine. Poseban napredak ostvaren je na polju ekonomske kooperacije: robna razmena je porasla sa 434 miliona dolara koliko je iznosila 1970. na preko 700 miliona dolara u 1973 (procena iz septembra te godine). Zaključen je međuvladin sporazum o kreditu u vrednosti od 540 miliona dolara, a saradnja se proširivala na građevinarstvo, poljoprivredu, saobraćaj i druga područja. ${ }^{35}$

Remont sovjetskih vojnih brodova bilo je jedino pitanje koje je moglo da nanese ozbiljniju štetu pozitivnom razvoju jugoslovensko-sovjetskih odnosa. Sovjetski ambasador V. Stepakov je, naime, 22. marta 1973. preneo Milošu Miniću, jugoslovenskom ministru inostranih poslova, poruku Andreja Gromika u kojoj se izražava interes sovjetske vlade da se njihovi vojni brodovi remontuju u jugoslovenskim remontnim zavodima na komercijalnoj osnovi. Posle temeljnog razmatranja ovog pitanja koje je ocenjeno politički osetljivim s obzirom na međunarodni položaj zemlje i njenu spoljnu politiku, nadležne jugoslovenske institucije: ministarstva inostranih poslova i odbrane i sekretarijat za zakonodavstvo zaključili su da ovu materiju treba regulisati zakonom kojim bi bili predviđeni uslovi za usluge remonta pod istim uslovima ratnim brodovima svih zemalja, i to isključivo na komercijalnoj osnovi. Odlučeno je (u junu) da se sovjetskom ambasadoru usmeno saopšti da postojeći zakonski propisi ne predviđaju remont ratnih brodova, zbog čega jugoslovenska vlada nije u mogućnosti da ovo pitanje reguliše međudržavnim sporazumom, ali da će uskoro (očekuje se do kraja godine), ova materija biti regulisana zakonom koji će važiti za remont ratnih brodova svih zemalja. ${ }^{36} \mathrm{Na}$ ovaj način, budući da se na tome nije dalje insistiralo, ovo osetljivo pitanje je bilo razrešeno bez značajnijih posledica po jugoslovensko-sovjetske odnose.

Dijalog na najvišem političkom nivou, uspostavljen prilikom posete Brežnjeva Jugoslaviji 1971. i produbljen i učvršćen Titovim posetama SSSR-u 1972. i 1973, predstavljao je vrlo dobru bazu za pozitivan razvoj i stabilnost političkih odnosa između dve zemlje kao i za sveukupan napredak bilateralne saradnje tokom cele te decenije.

${ }^{35}$ AJ, KPR, 837, I-3-a/101, Materijal o jugoslovensko-sovjetskim odnosima sačinjen povodom posete Alekseja Kosigina Jugoslaviji, septembar 1973.

${ }^{36}$ AJ, KPR, 837, I-5-b/99-25, Informacija povodom pitanja remonta sovjetskih vojnih brodova u jugoslovenskim remontnim zavodima, 18. jun 1973. Prema sovjetskom predlogu remont brodova, čija se vrednost procenjivala na 2 miliona dolara godišnje, počeo bi 1974. 
Đoko Tripković

\section{RENEWAL OF THE POLITICAL DIALOG BETWEEN THE BELGRADE AND MOSCOW AUTHORITIES IN 1970s}

\section{Summary}

At the beginning of 1970-ties Yugoslavia and Soviet Union asupmted that is nececssary to normalize the mutual relations, hampered after the Wasraw Pact military intervention in Czechoslovakia 1968. First practical step was visit of Soviet foreign minister Andrey Gromiko to Yugoslavia in September 1969, after which Tito decided to invite Soviet leader Leonid Brezhnyev to visit Yugoslavia too. It led to the Brezhnyev's visit to the Belgrade in September 1971, and talks with Tito. Prior to the visit, the normal bilateral cooperation was reestabilished, including the renewal of the military cooperation and econimcal trade. However, Tito-Brezhnyev talks leaded to growth of mutual confidence. The Soviets accepted the relations with Yugoslavia on the principles strongholded when Khrushchev visit Belgrade in 1955, which asupmted Yugoslavia's specific international position and it's foregin policy and its own model of the socialistic development. Brezhnyev's visit leaded to re-estabilishment and even imprtoved the political and econimical relations between the Soviet Union and Yugoslavia. Following relations have a storng impact on stabilisation of the Yugoslav internal situation, further development of the relations towards the Third World, and for some aspects in the inetrnational relations in the region, where China started to build its influence. Brezhnyev visit was followed by the Tito's visitis to USSR, in 1972 and 1973 which resulted in stornger political dia$\log$ betewen Belgrade and Moscow held on the highest political and party levels. It produced a further stability in Soviet-Yugoslav relations. 